\title{
VISUALIZATION AND PREDICTION OF LANDSCAPE DYNAMICS IN THE PROTECTED AREAS OF KARNATAKA
}

\author{
Bharath Setturu ${ }^{1}$, Nimish Gupta ${ }^{2}$, Ramachandra $\mathbf{T V}^{3}$

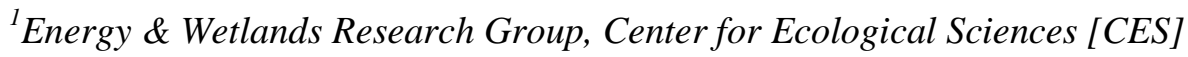 \\ ${ }^{2}$ Energy \& Wetlands Research Group, Center for Ecological Sciences [CES] \& Thapar University, Patiala, Punjab \\ 147004, India \\ ${ }^{3}$ Energy \& Wetlands Research Group, Center for Ecological Sciences [CES] \& Centre for Sustainable Technologies \\ (astra), Bangalore, Karnataka 560 012, India
}

\begin{abstract}
Protected areas are locations with the exceptional natural, cultural and ecological values and needs to be protected to ensure sustainable management and conservation of biodiversity. In India, there are 733 protected areas recognized by the Government which includes 103 National Parks, 537 Wildlife Sanctuaries, 26 Community Reserves and 67 Conservation Reservesto conserve biodiversity and to safeguard social, cultural,economic, ecological and health benefits. The protected areas will have reduced human activities which helps in conservation of flora and fauna of the region. Bandipur National Park (BANP) and Biligiri Ranganatha Temple (BRT) Tiger Reserve in southern Karnataka (Chamarajanagar, Mysore district) are considered to understand status and transition of forest cover at temporal scale. Bandipur National Park is considered one of the most beautiful National Parks of India, dominated by deciduous forest followed by scrub forest. BANP is blessed with many floral and faunal species some of which are endemic to the region (best known for large mammals). BRT Tiger reserve is at a height of $5091 \mathrm{ft}$. above sea level with crest and troughs and has variable climatic condition which makes it suitable for diverse of flora and fauna. BRT Tiger reserve is the connector between Western and Eastern Ghats. Both the protected areas have a large population of tiger and elephant. Human-animal conflict is high in case of BANP. Both the protected areas face a major problem of frequent forest fire which is either natural or man-made. These fires burn huge amount of forest and affect the biodiversity of the region. Some of the other problems in these protected areas are deforestation activities, invasion of exotic weeds, poaching activities, encroachment to increase the agricultural areas, grazing of cattle within the protected area, illegal logging of wood, increased population in the protected area, etc. The main objective of the study is to understand the landscape dynamics in the study area and predict the likely changes which can occur by 2026 using CA-Markov model. This will help in creating an appropriate conservation measures which can be site specific by involving all the stake holders
\end{abstract}

Keywords: Protected Areas, National Parks, Tiger Reserves, Land Use/ Land Cover, CA-Markov, Biodiversity $* * *$

\section{INTRODUCTION}

Forest cover around $1 / 3^{\text {rd }}$ of earth's land surface, plays a critical role in human livelihood, ecosystem management and health [1] and in various environmental and socioeconomic functions [2, 3] at local to global scales.The incessant land use/ land cover (LULC) alterations due to increased human activities have affected the environment at global scale [4]. During the last 3 decades, India has lost a substantial spatial extent of forestsdue to fire,many industrial projects and encroachments [5]. Increasing frequency and extent of forest fire have played a major role in forest fragmentation and land use changes. The fire results in deteriorating the forest health, etc., while releasing GHGs in atmosphere [6] which further affects human health and alters the climate at micro and macro level and the biodiversity [4]. Loss of biodiversity not only refers to species extinction but also affects productivity of ecosystem. It is a matter of concern because of its huge impact on human beings and ecosystem functioning [7]. The invasive exotic plant species play a major role in expansion of fire. The nature, severity and extent of forest fire varies widely, depending on the type of region, type of vegetation, weather
etc.The forest fire alters composition of vegetation such asconversionfrom deciduous forest into scrub forest or barren land (LU change). Alteration in LU patterns have also led to changes in various biogeochemical cycles.Forest loss accounted to be around 1.5 million square kilometres globally from 2000 to 2012 [8], which emphasizes monitoring the landscape dynamics to ensure the sustainability of natural resources and mitigation of changes in the climate.

Knowledge of LU dynamics helps in evolving appropriate management strategies with sustainable land management plansto conserve biodiversity, preventing forest fires and mitigate environmental changes [9, 10]. Availability of remote sensing data at regular intervals since 1972 has played a significant role in monitoring and visualizing the land use changes $[11,12]$. Geo-visualization and modelling helps to explore the complex behaviour [13], which helps in understanding the causes and consequences of the change. Modelling approaches are useful to make an accurate assessment of the LULC changes, drivers of change, probable impacts on ecosystem, etc. [14]. There are various 
models with relative merits to assess and monitor LULC changes such as Clue-S, Markov model, CA-Markov model, etc. Markov model only considers the temporal changes in landscape but fails to provide the spatial changes. Thus a combination of CA-Markov is used which takes into account spatial as well as temporal data $[15,16]$. Forest changes are nonlinear in nature and CA-Markov gives better results for nonlinear dynamics, thus, the model was chosen. Markov model produces transition matrices (transition probability matrix and transition area matrix) of altering of one land use type to another. Then CA model provides transition/reclassification rules depending on the previous state and neighbourhood pixels of the current pixel under study. CA-Markov model evaluates multiple criteria and predicts the future change using probability matrices and reclassification rules $[17,18,19]$. The current study aims to assess landscape dynamics in the protected areas of Southern Karnataka.

The objectives of the current study are: i) assessing landscape dynamics during 1973 - 2016 and ii) visualization of likely spatial patterns of land uses in 2026 using CAMarkov model.

\section{STUDY AREA}

Karnataka is blessed with most magnificent and diverse forests - with lush evergreen forests in Western Ghats to scrubs in the plains and sholas in the heavy rainfall regions. It is one of the highly biodiversity rich regions in India because of its great diversity in climate, topography and soil. The different environmental regimes supportdiverse flora and fauna, some of which are endemic to the region. The state has around 4500 species of flowering plants, 600 bird species, 160 species of each mammals and reptiles, 800 species of fish, 70 species of frog, etc. Karnataka supports $25 \%$ of the elephant population and $10 \%$ of tiger population of the country. Karnataka has a total forest cover of $22.60 \%$ (43356 $\mathrm{km}^{2}$ ) with 5 national parks and 27 wildlife sanctuaries. [20]. This study has been done in two protected areas - Bandipur National Park (BANP) and Biligiriranganatha Temple Tiger Reserve (BRTTR) as shown in Figure 1. BANP is a part of India's biggest biosphere reserve called "Nilgiri biosphere reserve" (Together with Mudumalai Wildlife Sanctuary in Tamil Nadu, Wayanad Wildlife Sanctuary in Kerala and Nagarahole National Park in North).Table 1 shows the demographic and geographic information.

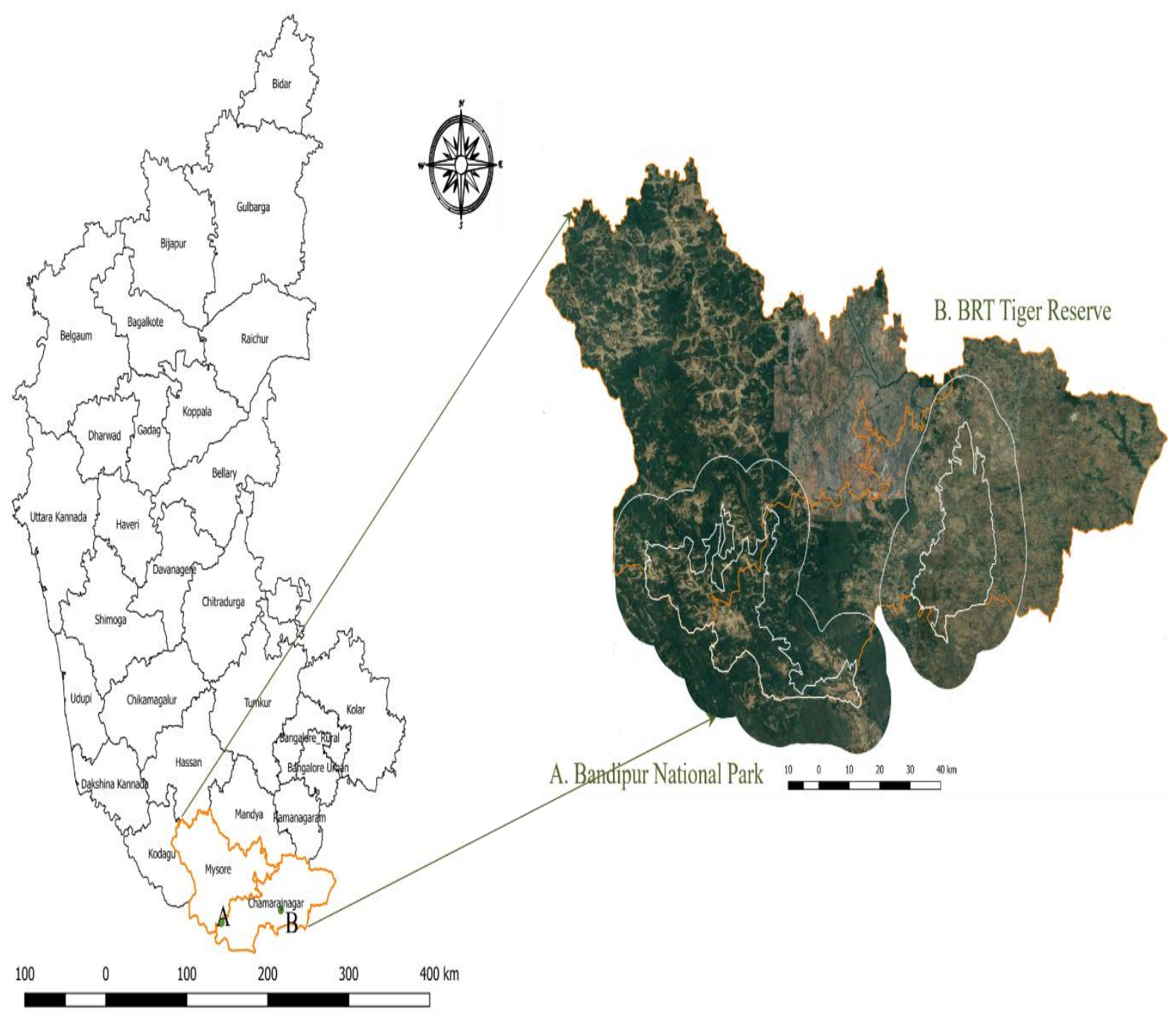

Fig 1: Study Area: A. BANP, B. BRTTR 
Table 1: Protected Areas: Geographic and Demographic Information

\begin{tabular}{|c|c|c|}
\hline Protected Area & Bandipur National Park & BRT Tiger Reserve \\
\hline $\begin{array}{l}\text { Notified under section of WPA, } \\
1972 \text { as (amended up to 2003) } \\
\text { (Final Notification) }\end{array}$ & Section 35 ( 4 ) & Section 26 ( A) (b) \\
\hline Year of Establishment & 2001 & 1994 \\
\hline Latitude & $11^{\circ} 35^{\prime} 34^{\prime \prime}$ and $11^{\circ} 55^{\prime} 02^{\prime \prime}$ North & $11^{\circ} 43^{\prime}$ to $12^{\circ} 08^{\prime}$ North \\
\hline Longitude & $76^{\circ} 12^{\prime} 17^{\prime \prime}$ and $76^{\circ} 51^{\prime} 32^{\prime \prime}$ East & $77^{\circ} 00^{\prime}$ to $77^{\circ} 16$ East \\
\hline Area & 872.24 Sq. Km & 539.52 Sq. Km \\
\hline District & $\begin{array}{l}\text { Mysore(Nanjungud and H.D. Kote taluks) and } \\
\text { Chamarajanagar(Gundlupet taluk) }\end{array}$ & Chamarajanagar \\
\hline Circle & APCCF Field Director Project Tiger, Mysore & CCF, Chamarajanagar Circle \\
\hline Forest Division & CF \& Director Bandipur & CF \& Director Chamarajanagar \\
\hline Vegetation & $\begin{array}{l}\text { East - stunted trees, interspersed with bushes } \\
\text { and open grassy patches; Northwest - a gradual } \\
\text { shift in the vegetation from open dry deciduous } \\
\text { forests to tropical mixed deciduous forests }\end{array}$ & $\begin{array}{l}\text { Scrub, Deciduous, Riparian, } \\
\text { Evergreen, Sholas and Grasslands }\end{array}$ \\
\hline Flora & 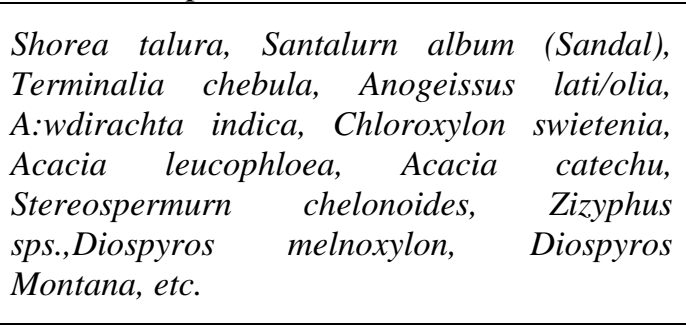 & $\begin{array}{l}\text { Anogeissus latifolia, Dalbergia } \\
\text { paniculata, Baswellia serrata, } \\
\text { Commiphora caudate Acacia } \\
\text { chundra, Diospyros melanoxylon, } \\
\begin{array}{l}\text { Elaeocarpus tuberculatus, } \\
\text { syzygium malabaricum, } \\
\text { Schefflera capitata, Cucurma } \\
\text { neilgherrensis, etc. }\end{array}\end{array}$ \\
\hline Fauna & $\begin{array}{l}\text { Elephant, Tiger, Large guar, Chital, Leopard, } \\
\text { Porcupine, Jackal, Giant squirrel, Sloth bear, } \\
\text { Mouse deer, Python, Indian monitor, Quails, } \\
\text { Partridges, Malabar trogon, Malabar grey } \\
\text { hornbill, Blue wing parakeet, White bellied } \\
\text { minivet, etc. }\end{array}$ & $\begin{array}{l}\text { Elephants, Indian gaurs, Tigers, } \\
\text { Leopards, Wild dogs, Butterflies, } \\
\text { Reptiles, Lesser cats, Sloth bears, } \\
\text { Sambars, Chitals, Barking deer, } \\
\text { Four horned antelopes, Flying } \\
\text { squirrel }\end{array}$ \\
\hline Rainfall & $776.7 \mathrm{~mm}$ & $1300 \mathrm{~mm}$ to $1500 \mathrm{~mm}$ \\
\hline
\end{tabular}

\section{METHOD}

Figure 2 outlines the method followed which includes - (1) Data collection and Pre-processing, (2) Land use analysis and (3) Modelling and Prediction.

\subsection{Data Collection and Pre-processing}

Remote sensing data includes Landsat 1 - MSS (1973), Landsat 5 - (1991), IRS p6L4X (2016) and Google Earth (http://earth.google.com). Landsat data having good resolution and also being cost effective (as it is available free of cost and can be downloaded from public domains such as USGS (http://glovis.usgs.gov, http://earthexplorer.usgs.gov) was used. IRS p6L4X was procured from NRSC, Hyderabad (http://nrsc.gov.in). Geometric correction was done for primary data by taking GCPs (ground control points) with the help of secondary data. The geometrically corrected Landsat data was then resampled to $30 \mathrm{~m}$. IRS data was analysed at $5 \mathrm{~m}$ for better precision of land uses. However, for modelling IRS data was resampled to $30 \mathrm{~m}$. The data was then cropped corresponding to the study area with a buffer region of $10 \mathrm{~km} \mathrm{[21,22,23].}$ 


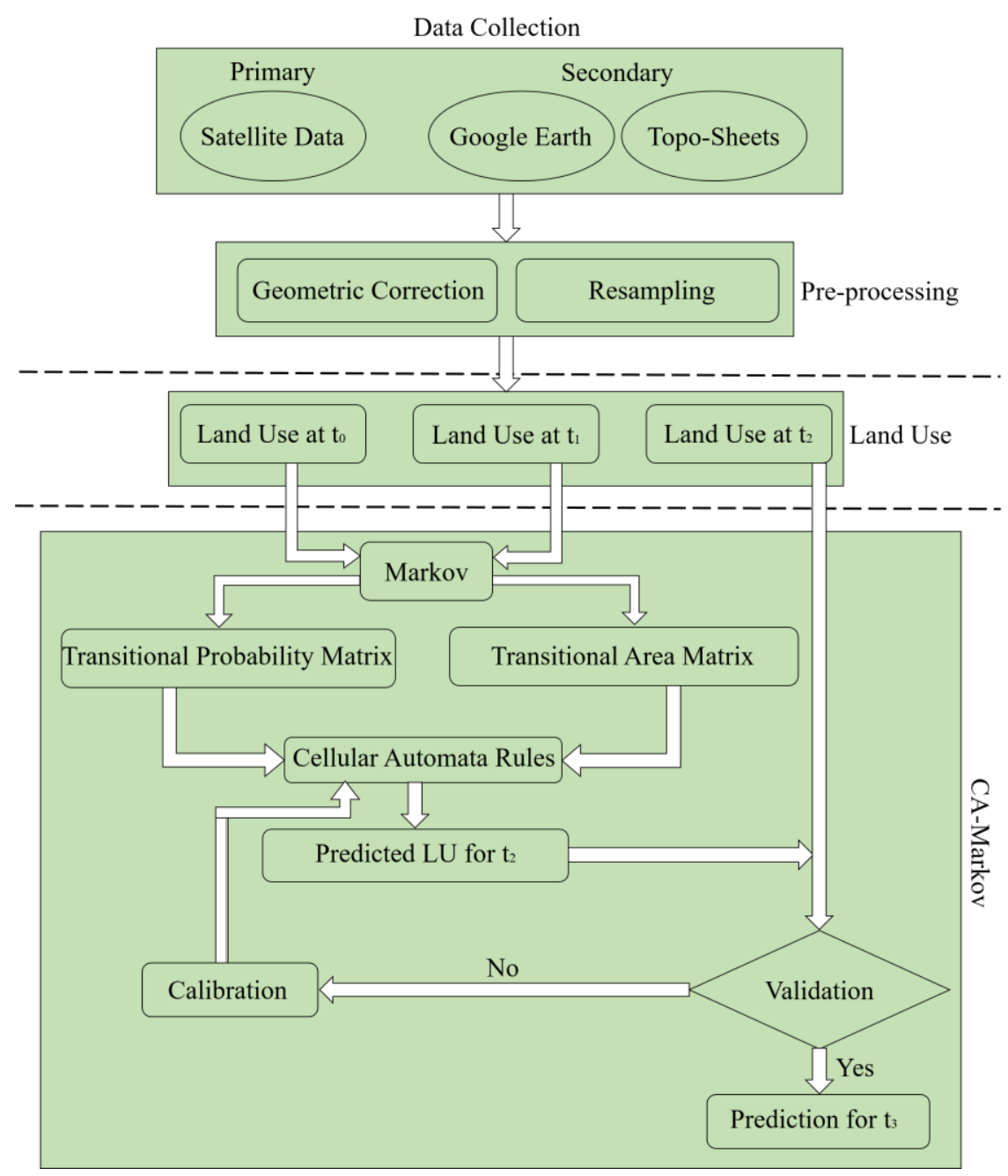

Fig 2: Spatial Analyses: Pre-Processing, Classification and Modelling

\subsection{Land Use Analysis}

Land use analysis was carried out in 3 steps:

a. Creation of FCC (false color composite) - This was done by assigning Blue band $\rightarrow$ Green band data, Green band $\rightarrow$ Red band data and Red band $\rightarrow$ Near Infrared Data.

b. Training the classifier - In this the training polygons were chosen on the FCC corresponding to heterogeneous patches for each land use class. This was done by overlaying the FCC on Google earth to cross check the polygon selected for specific land use class using QGIS. These polygons should cover at least 15\% of the total area of interest (AOI) and should be uniformly distributed across the AOI.

c. Classification - The training polygons were converted as signatures using GRASS-GIS and were assigned to various land use classes. Then land use analysis was carried out by using Gaussian maximum likelihood classification algorithm (Supervised classification). This classifier performs the classification based on probability density function and is considered as one of the most superior methods [24]. The remotely sensed data was classified based on the signatures created from training polygons which includes all land use types as mentioned in Table 2. Land use dynamics were assessed by using the land use classificationsof the temporal data $[21,22,23]$.

Table 2: Land Use Classes

\begin{tabular}{|c|c|c|}
\hline $\begin{array}{l}\text { S } \\
\text { No. }\end{array}$ & $\begin{array}{l}\text { Land use } \\
\text { class }\end{array}$ & $\begin{array}{l}\text { Land uses included in the } \\
\text { class }\end{array}$ \\
\hline 1 & $\begin{array}{l}\text { Evergreen } \\
\text { Forest }\end{array}$ & $\begin{array}{l}\text { Evergreen forest, Semi- } \\
\text { Evergreen forest }\end{array}$ \\
\hline 2 & Deciduous & $\begin{array}{l}\text { Moist Deciduous forest, Dry } \\
\text { Deciduous forest }\end{array}$ \\
\hline 3 & & $\begin{array}{l}\text { Scrubs and grasses, } \\
\text { Grasslands }\end{array}$ \\
\hline 4 & \begin{tabular}{|l|} 
Forest \\
Plantation
\end{tabular} & $\begin{array}{l}\text { Plantations done across the } \\
\text { forest by forest department }\end{array}$ \\
\hline 5 & Horticulture & $\begin{array}{l}\text { Plantation on agricultural } \\
\text { lands }\end{array}$ \\
\hline 6 & Agriculture & $\begin{array}{l}\text { Current sown, fallow } \\
\text { agricultural land }\end{array}$ \\
\hline 7 & & Lakes, reservoirs, ponds \\
\hline 8 & $\mathrm{U}$ & \\
\hline 9 & Open Area & $\begin{array}{l}\text { Rock, Queries, Abandoned } \\
\text { mining sites, others }\end{array}$ \\
\hline
\end{tabular}




\subsection{Modelling and Prediction}

Markov provided information about the transition or occurrence of temporal changes. It provides transitional probability matrix which gives information about the probability of one land use class likely to changeinto other land use class and transition area matrix which provides the likely quantification of land use class changing in terms of area. These matrices are obtained based on probability distribution of the next state of current cell which is dependent on current state only. Transitional probability matrix and transitional area matrix can be calculated by equation 1 and 2 .

$$
P=\left[\begin{array}{ccc}
P_{11} & P_{12} & \ldots P_{1 n} \\
\vdots & \vdots & \vdots \\
P_{n 1} & P_{n 2} & \ldots
\end{array}\right.
$$

Where, $\mathrm{P}$ is the Transitional probability matrix; $\mathrm{P}_{\mathrm{ij}}$ is the probability of $i^{\text {th }}$ land use to convert into $\mathrm{j}^{\text {th }}$ class during the transition period; $\mathrm{n}$ is the number of land use classes.

$$
A=\left[\begin{array}{ccc}
A_{11} & A_{12} & \ldots A_{1 n} \\
\vdots & \vdots & \vdots \\
A_{n 1} & A_{n 2} & \ldots
\end{array}\right.
$$

Where, $\mathrm{A}$ is the Transitional area matrix; $\mathrm{P}_{\mathrm{ij}}$ is the sum of area of $i^{\text {th }}$ land use to convert into $\mathrm{j}^{\text {th }}$ class during the transition period.

Cellular Automata provides the reclassification rules based on which the state of cell changes with respect to the state of neighbourhood cells of previous state of the cell under consideration. These rules are defined by the interpreter and can be region specific or can be used globally.

CA-Markov method involves Markov model output and gives it as input to Cellular automata so that both temporal as well as spatial variations can be considered and thus providing better results. The land use for future is predicted by using equation 3 .

$$
L_{(t+1)}=P * L_{(t)}
$$

Where, $\mathrm{L}_{(\mathrm{t}+1)}$ is the land use status at time $\mathrm{t}+1 ; \mathrm{L}_{(\mathrm{t})}$ is the land use status at time $t$.

A contiguity filter of kernel size $5 \times 5$ was used. It was used to create a weighing factor so that the cells far from existing land use have lower effect when compared to nearby cells [25]. The filter used is as shown.

$$
\left[\begin{array}{lllll}
0 & 0 & 1 & 0 & 0 \\
0 & 1 & 1 & 1 & 0 \\
1 & 1 & 1 & 1 & 1 \\
0 & 1 & 1 & 1 & 0 \\
0 & 0 & 1 & 0 & 0
\end{array}\right]
$$

\section{RESULTS AND DISCUSSION}

\subsection{Land Use Analysis}

The temporal land use analysis for BANP and BRTTR was performed for 1973, 1991 and 2016. Figure 3 provides the pictorial representation and Figure 4,5 provides the quantification of each land use class for BANP and BRTTR respectively. Land use analysis of BANP shows a decrease in deciduous forest $(14.39 \%)$ and increase in scrub forest cover $(18.71 \%)$. It is also observed some of the deciduous forest is being converted into scrub forest at temporal scale due to fire and various factors. The increment in built-up area signifies increase in population which can be considered as main reason for conversion of dense forest into sparse forest. BANP also facing many faces many other problems such as poaching, encroachments, illegal logging of fuel-wood, grazing of cattle within the protected area, infestation of weed, etc.

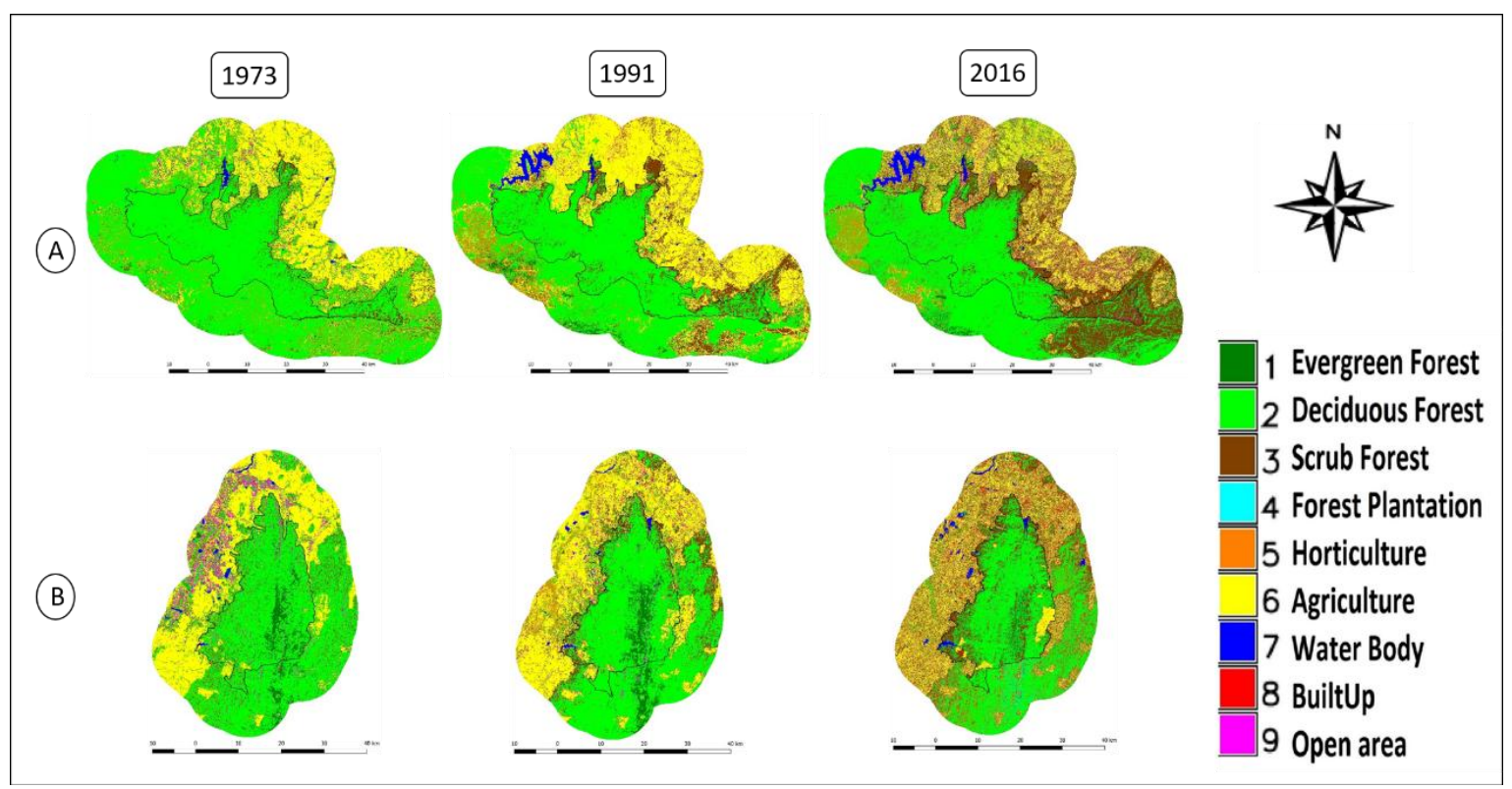

Fig 3: Land Use analysis with $10 \mathrm{Km}$ buffer region for (A) BANP, (B) BRTTR 


\section{Bandipur National Park}

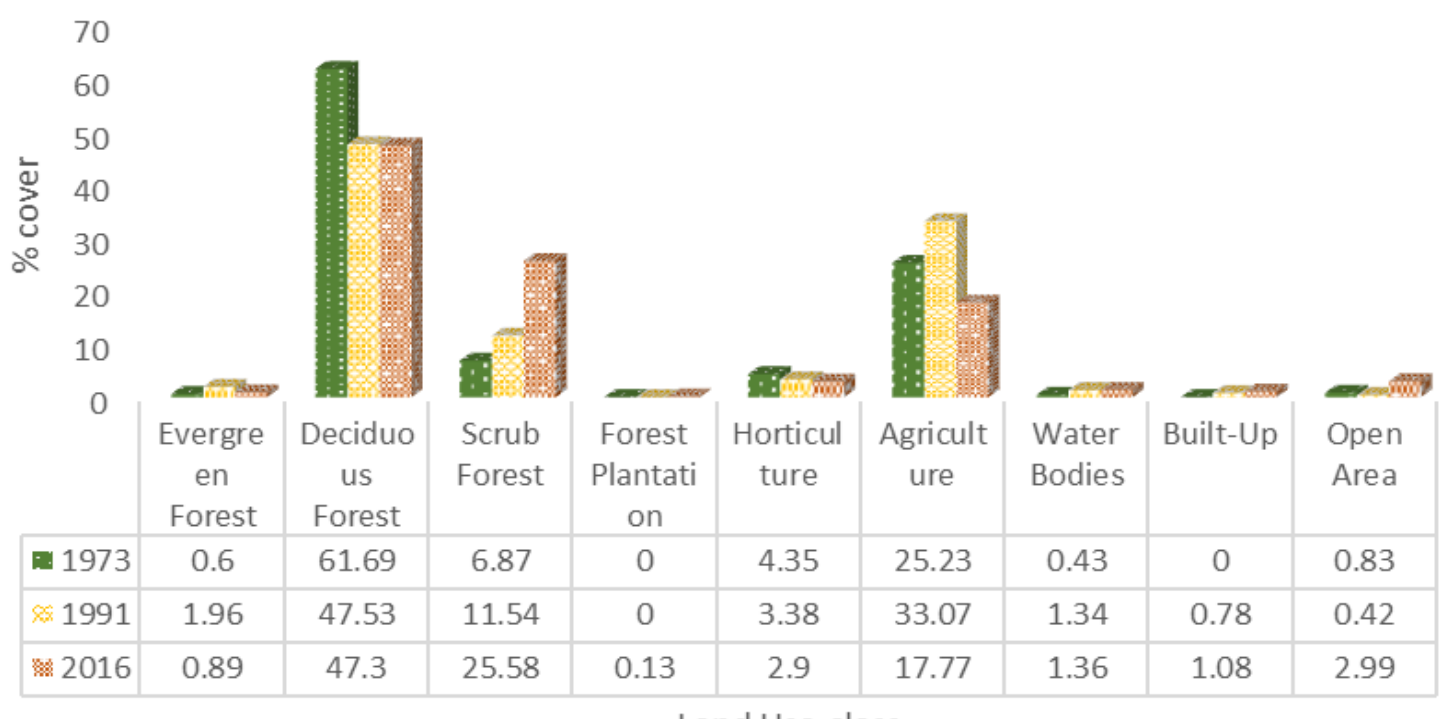

Land Use class

Fig 4: Land use in BANP with $10 \mathrm{Km}$ buffer

The land use analysis of BRTTR shows decrease in evergreen forest by $3.71 \%$ and deciduous forest by $13.05 \%$ (1973-2016). Increment in scrub forest (14.80\%) signifies the conversion of dense forest to sparse forest. The agricultural activities in the region is reduced and horticulture has increased which shows that people in the region have moved to more commercial plantations. The increase in built-up area can be the main reason for degradation. The tribal Soligas are residents of BRT, extract non-timber products and also practice shifting agriculture and hunting. Another reason of degradation can be the religious activities practiced within the wildlife sanctuary (BR Temple).

\section{BRT Tiger Reserve}

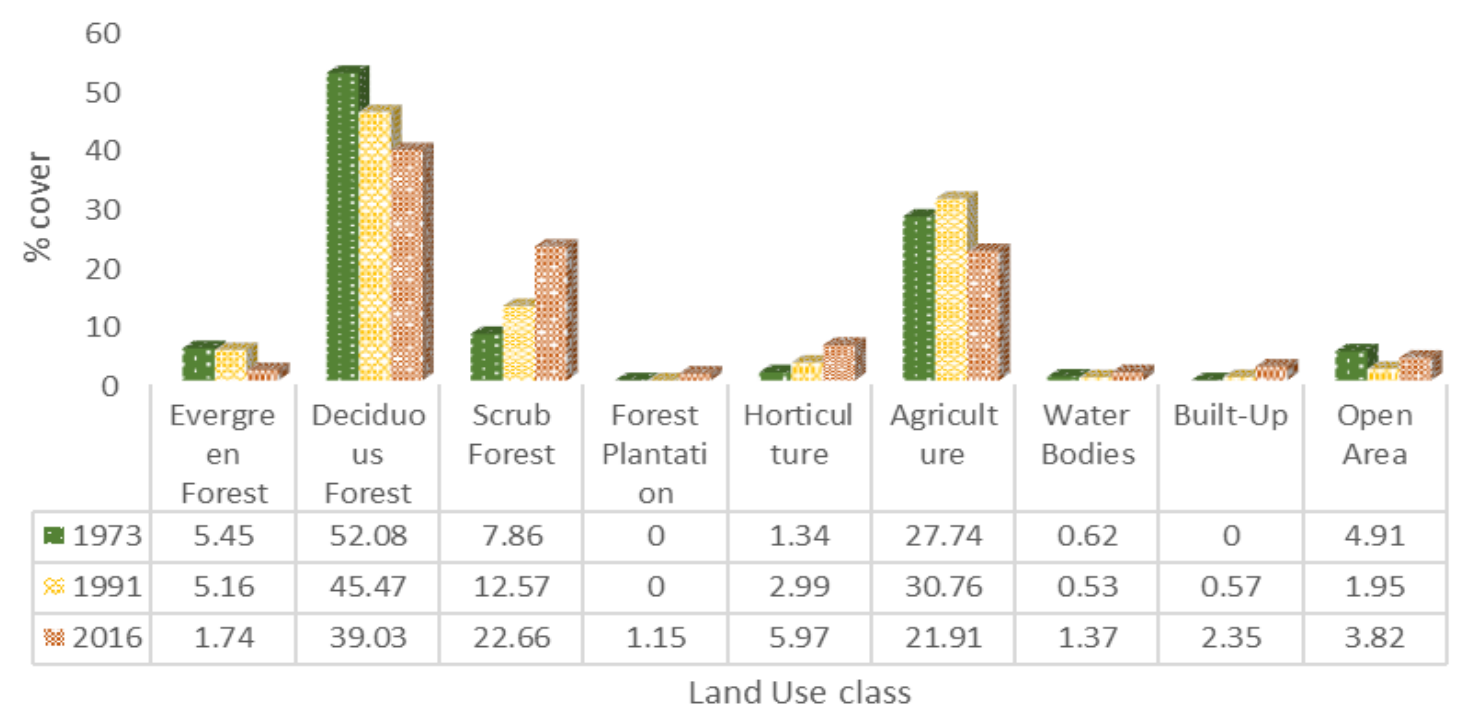

Fig 5: Land use in BRTTR with $10 \mathrm{~km}$ Buffer

Forest fire is another serious problem in BANP as large tracts of forests were prone to fire due to human induced (rarely natural). Table 3 explains the extent of forest fire recent time period and Figure 6 shows burnt/affected areas asper 2014. 


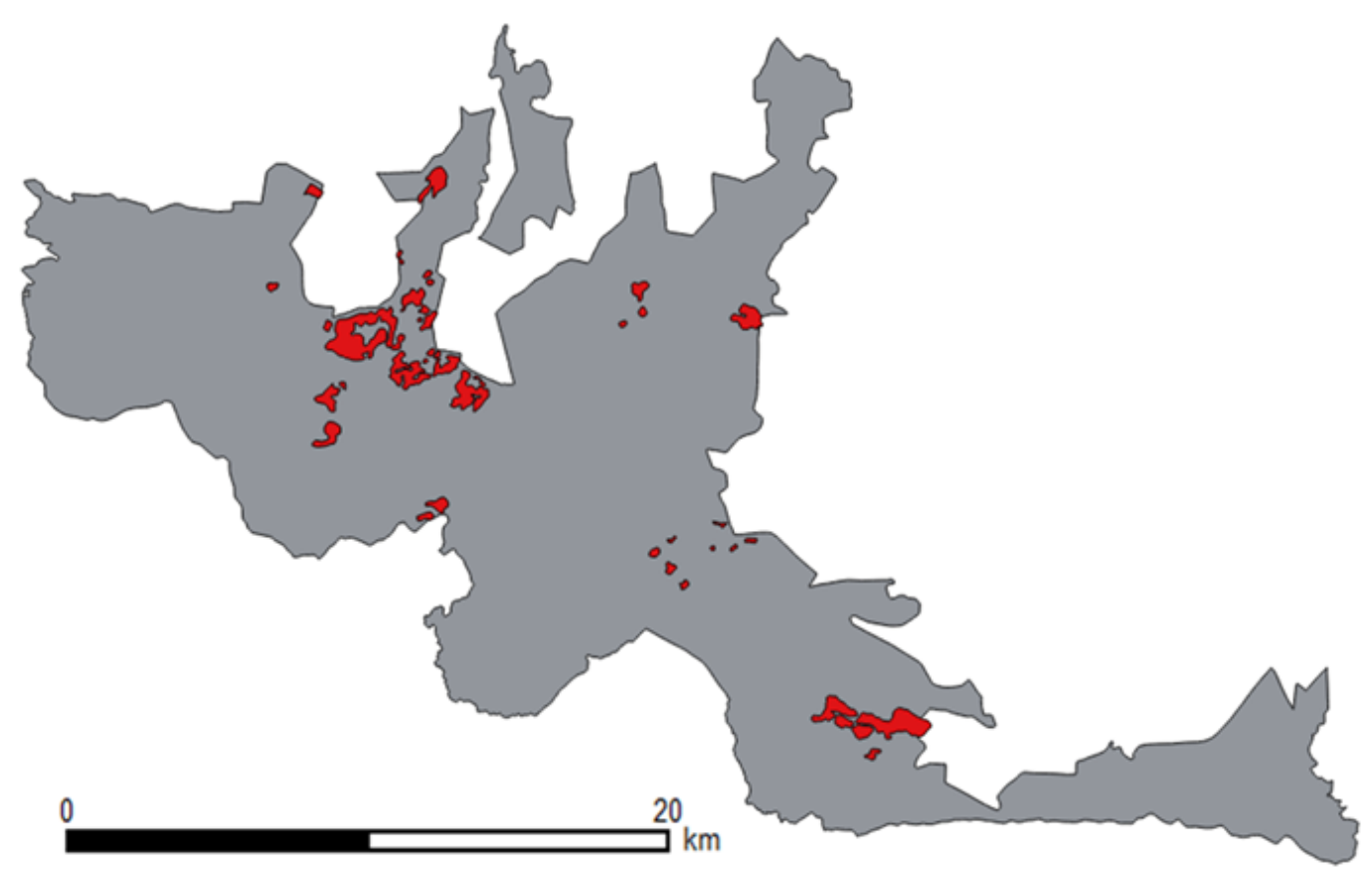

Fig 6: Burnt/affected areas (Source: bhuvan.nrsc.gov.in)

Table 3: Recent forest fire in BANP

\begin{tabular}{|l|l|l|l|}
\hline Year & Month & Area Burnt (Ha) & Source \\
\hline $\mathbf{2 0 1 4}$ & March & 2627.707 & BHUVAN (http://bhuvan.nrasc.gov.in) \\
\hline $\mathbf{2 0 1 6}$ & February & 54 & The Hindu, Mysore, 22 Feb, 2016 \\
\hline $\mathbf{2 0 1 6}$ & March & 81 & Deccan Herald, Chamarajanagar, 9 Mar, 2016 \\
\hline $\mathbf{2 0 1 7}$ & February & 303.50 & Indian Express, Mysore, 20 Feb, 2017 \\
\hline
\end{tabular}

\subsection{Modelling and Prediction}

Land uses for 1973, 1991 and 2016 were analysed. Land use of 1973 and 1991 was used for simulation of 2016 land use map. The simulated result was then compared with the actual land use of 2016 for validation process. Simulation was done by using reclassification rules, to calibrate the model and verified, if calibration is inaccurate and the process was repeated. Figure 7 and Figure 8, 9 shows the simulated results for BANP and BRTTR respectively.Table 4 shows the validation results of the model with which we can say that there is a good agreement in the actual and the predicted maps of 2016.The results show that in BANP will follow the same trend of degradation from dense forest to sparse forest in eastern side. The agricultural and horticultural activities are likely to remain in same composition while the built-up area is predicted to increase which provides the major cause of degradation. Considering the case of BRTTR, here also the deciduous forest is reducing and the forest plantation and agricultural activities are likely to increase slightly. The reason being likely increase in built-up area and in turn the human population within the buffer region. Both the protected area shows continuous forest lossin near future emphasizing the need for effective management to arrest further degradation. 


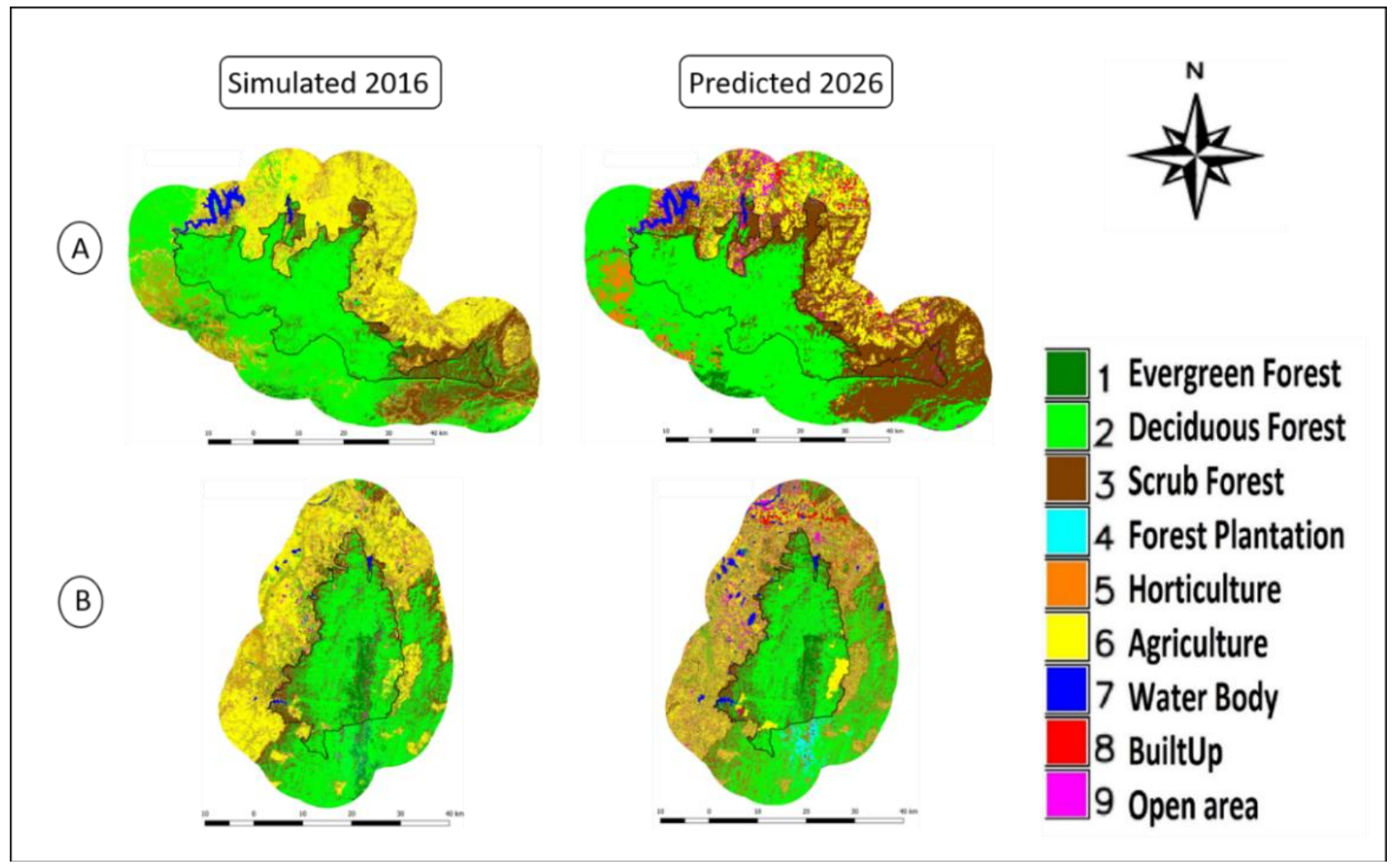

Fig 7: Predicted Land Use analysis with $10 \mathrm{Km}$ buffer region for (A) BANP, (B) BRTTR

\section{Bandipur National Park}

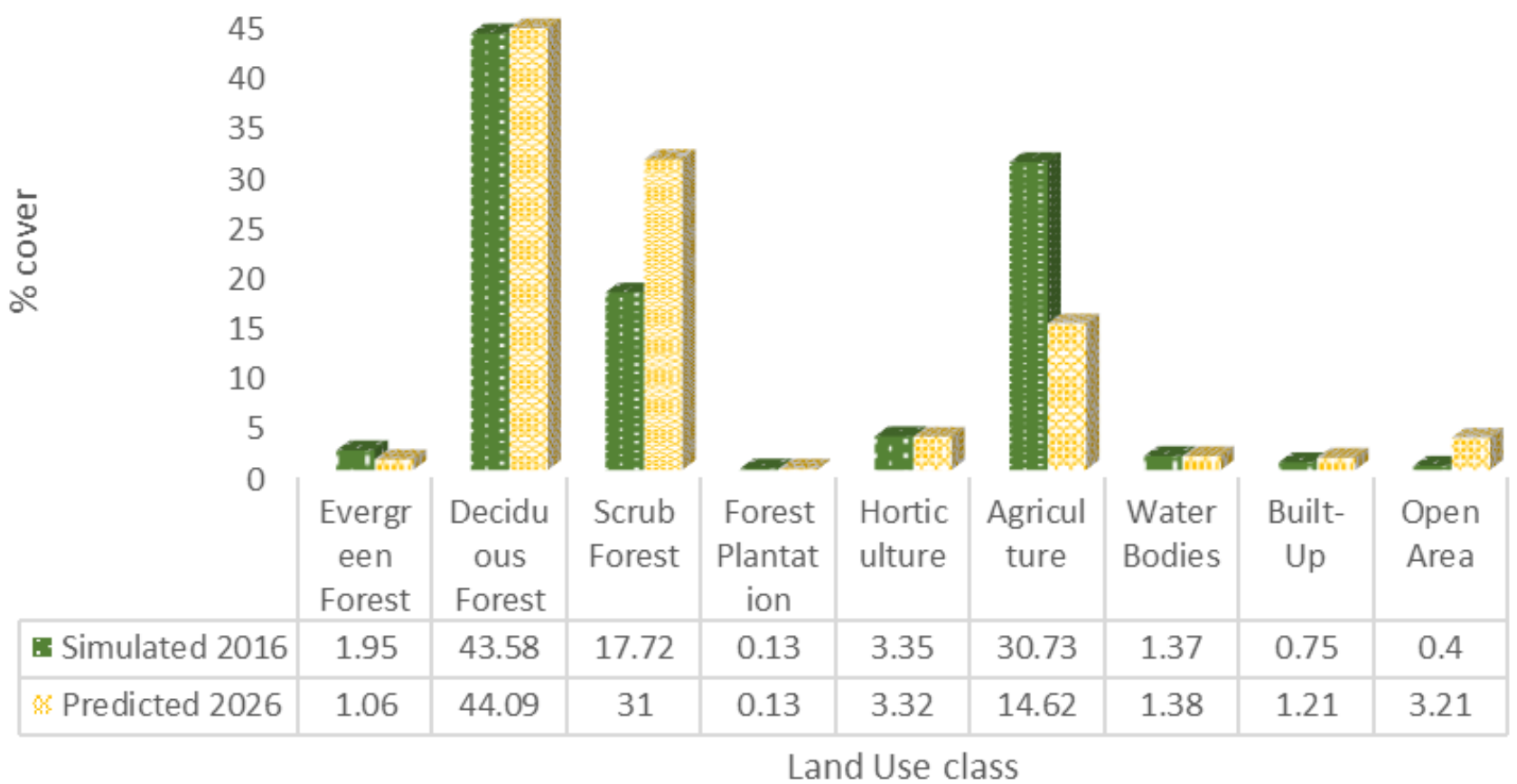

Fig 8: Predicted Land Use analysis for BANP with $10 \mathrm{Km}$ buffer region 


\section{BRT Tiger Reserve}

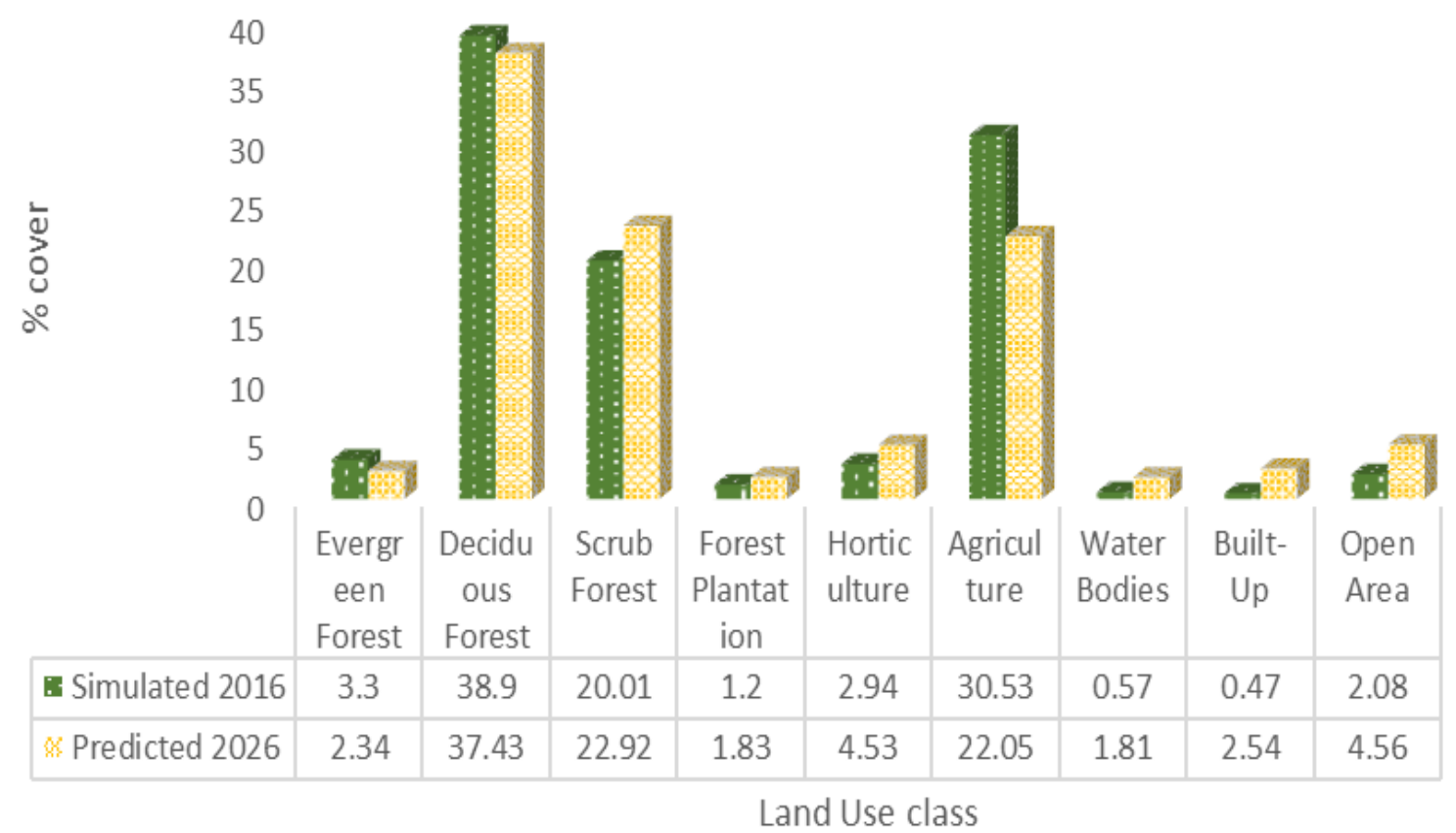

Fig 9: Predicted Land Use analysis for BRTTR with $10 \mathrm{Km}$ buffer region

Table 4: Validation between predicted and actual image

\begin{tabular}{|c|l|l|}
\hline Index & Bandipur National Park & BRT Tiger Reserve \\
\cline { 2 - 3 } & Predicted 2016 & \\
\hline $\mathbf{K}_{\mathbf{n o}}$ & 0.82 & 0.87 \\
\hline $\mathbf{K}_{\text {location }}$ & 0.86 & 0.82 \\
\hline $\mathbf{K}_{\text {standard }}$ & 0.75 & 0.75 \\
\hline
\end{tabular}

\section{CONCLUSION}

The land use changes in two protected areas were assessed using remote sensing data of 1973, 1991 and 2016. The analyses highlight the loss of deciduous forest cover, increased fragmentation and more importantly spread of invasive species.Both the regions facefrequent fires due to invasive weeds and also disturbances caused by anthropogenic activities.In the span of four decades, conversion of dense forest into sparse forest is observed to be of $14.49 \%$ and $16.76 \%$ in BANP, BRT respectively. Modelling also indicated the future changes in configuration of forest. Accuracy of analysis shows that CA-Markov model has efficiently simulated the land use change based on the transition matrices and reclassification rules. However, the model is limited to its neighbourhood behaviour and lacks in consideration of human decision making, socio-economic variables and environmental impacts. The results indicate that even though the forests have been assigned the status of National Park and Tiger Reserve, the fragmentation continues to be the major threat for conservation of endemic taxa and sustenance of natural resources. Monitoring taking advantages with the advances of spatial technologies helps to minimise the man-made forest fires in the protected areas.

\section{ACKNOWLEDGEMENT}

We are grateful to (i) the Ministry of Environment, Forest and Climate Change, (ii) NRDMS Division, The Ministry of Science and Technology, Government of India, (iii) Karnataka Forest Department, (iv)Comptroller and Auditor General of India, AG's Office, Karnataka and (v) Indian Institute of Science for the financial, data and infrastructure support.

\section{REFERENCES}

[1] Lindquist, E.J., D'Annunzio, R., Gerrand, A., MacDicken, K., Achard, F., Beuchle, R., Brink, A., Eva, H.D., Mayaux, P., San-Miguel-Ayanz, J. and Stibig, H.J., 2012. Global forest land-use change 1990-2005. FAO/JRC.

[2] Upgupta, S., Sharma, J., Jayaraman, M., Kumar, V. and Ravindranath, N.H., 2015. Climate change impact and vulnerability assessment of forests in the Indian Western Himalayan region: A case study of Himachal Pradesh, India. Climate Risk Management, 10, pp.63-76.

[3] Thomas Baldauf, Daniel Plugge, Aziza Rqibate and Michael Kohl, 2009. Case studies on measuring and 
assessing forest degradation: monitoring degradation in the scope of REDD.

[4] Setturu, B., Rajan, K.S. and Ramchandra, T.V., 2014, December. Status and future transition of rapid urbanizing landscape in Central Western Ghats-CA based approach. In ISPRS Technical Commission VIII Symposium (pp. 09-12).

[5] In just 30 years, India has lost large forests to 23, 716 industrial projects (2016) Available at: https://scroll.in/article/809286/in-just-30-years-indiahas-lost-large-forests-to-23716-industrial-projects (Accessed: 6 March, 2017).

[6] Ross, W. Gorte and Kelsi Bracmort, 2012. Forest Fire/Wildlife Protection. Congressional Research Service, 7-5700.

[7] Biggs, R., Simons, H., Bakkenes, M., Scholes, R.J., Eickhout, B., van Vuuren, D. and Alkemade, R., 2008. Scenarios of biodiversity loss in southern Africa in the 21st century. Global Environmental Change, 18(2), pp.296-309.

[8] Hansen, M.C., Potapov, P.V., Moore, R., Hancher, M., Turubanova, S.A., Tyukavina, A., Thau, D., Stehman, S.V., Goetz, S.J., Loveland, T. R., Kommareddy, A., Egorov, A., Chini, L., Justice C.O., and Townshend, J.R.G., 2013. High-Resolution Global Maps of $21^{\text {st }}$ Century Forest Cover Change Science, 342.

[9] Veldkamp, A., Lambin, E.F., 2001. Predicting landuse change. Agriculture Ecosystems and Environment, 85(1-3), pp. 1-6.

[10] Verburg P.H., Overmars, K., 2009. Combining topdown and bottom-up dynamics in land use modelling: exploring the future of abandoned farmlands in Europe with the Dyna-CLUE model. Landscape Ecology, 24:1167-1181.

[11] Miranda, A., Altamirano, A., Cayuela, L., Lara, A. and González, M., 2016. Native forest loss in the Chilean biodiversity hotspot: revealing the evidence. Regional Environmental Change, pp.1-13.

[12] Clark, J.S., Carpenter, S.R., Barber, M., Collins, S., Dobson, A., Foley, J.A., Lodge, D.M., Pascual, M., Pielke, R., Pizer, W. and Pringle, C., 2001. Ecological forecasts: an emerging imperative. Science, 293(5530), pp.657-660.

[13] Setturu, B., Rajan, K.S. and Ramchandra, T.V., 2014, November. Visualization of Forest Transition in Uttar Kannada. In Lake 2014: Conference on Conservation and Sustainable Management of Wetland Ecosystem in Western Ghats - 2016, 13-15 November.

[14] Haase, D., Schwarz, N., 2009. Simulation models on humannature interactions in urban landscapes-a review including system dynamics, cellular automata and agent-based approaches. Living Reviews in Landscape Research, 3, 2.

[15] Li, S.H., Jin, B.X., Wei, X.Y., Jiang, Y.Y. and Wang, J.L., 2015. Using Ca-Markov Model to Model the Spatiotemporal Change of Land Use/cover in Fuxian Lake for Decision Support. ISPRS Annals of the Photogrammetry, Remote Sensing and Spatial Information Sciences, 2(4), p.163.
[16] Ramachandra, T.V., Setturu, B., Rajan, K.S. and Chandran, M.S., 2016. Stimulus of developmental projects to landscape dynamics in Uttara Kannada, Central Western Ghats. The Egyptian Journal of Remote Sensing and Space Science, 19(2), pp.175193.

[17] Verburg, P.H., de Nijs, T.C., van Eck, J.R., Visser, H. and de Jong, K., 2004. A method to analyse neighbourhood characteristics of land use patterns. Computers, Environment and Urban Systems, 28(6), pp.667-690.

[18] Hagoort, M., Geertman, S. and Ottens, H., 2008. Spatial externalities, neighbourhood rules and CA land-use modelling. The Annals of Regional Science, 42(1), pp.39-56.

[19] Pontius, R.G., Shusas, E. and McEachern, M., 2004. Detecting important categorical land changes while accounting for persistence. Agriculture, Ecosystems \& Environment, 101(2), pp.251-268.

[20] Welcome to Karnataka Forest Department: (2016) Available at: http://www.aranya.gov.in/Home.aspx (Accessed: 7 February 2017).

[21] Ramachandra, T.V., Setturu, B., Nimish Gupta, Bhargavi R. Sharma, 2017.Monitoring forest dynamics within and buffer regions of protected areas in Karnataka, India, Sahyadri Conservation Series 63, ENVIS Technical Report 117, CES, Indian Institute of Science, Bangalore 560012

[22] Nimish Gupta, Setturu, B., Ramachandra, T.V., 2016. Landscape dynamics in protected areas. In proceedings of $10^{\text {th }}$ Biennial Lake Conference -2016 , 28-31 December.

[23] Setturu, B., Ramachandra, T.V., 2016. Visualization of Landscape Dynamics in National Parks of Central Western Ghats, In proceedings of $10^{\text {th }}$ Biennial Lake Conference - 2016, 28-31 December.

[24] Nimish Gupta, Setturu, B., Ramachandra, T.V., 2017. Modelling Landscape Dynamics in Protected Areas, Karnataka, Indian Biodiversity Congress (IBC 2017), Vol 4, $10^{\text {th }}-12^{\text {th }}$ March, at Puducherry, India.

[25] Setturu, B., Rajan, K.S. and Ramchandra, T.V., 2015. FOSS4G: Prediction of forest cover transitions in Uttara Kannada, Central Western Ghats, OSGEOIndia: FOSS4G 2015 - Second National Conference "Open Source Geospatial Tools in Climate Change Research and Natural Resources Management" Volume: 2, 8-10 ${ }^{\text {th }}$ June 2015, at Dehradun, India. 